\title{
EFEKTIVITAS PELATIHAN SEFY UNTUK MENINGKATKAN EFIKASI DIRI DALAM PENGAMBILAN KEPUTUSAN KARIR SISWA
}

\section{EFFEKTIVENESS OF SEFY TRAINING TO INCREASE SELF EFFICACY ON CAREER DECISION MAKING AMONG STUDENTS}

\author{
Aldika Rismawati Hamzah \\ Zakarija Achmad \\ Muhammad Shohib \\ Fakultas Psikologi Universitas Muhammadiyah Malang \\ Email :mshohib@umm.ac.id
}

\begin{abstract}
The purpose of this research was to find out the effect of SEFY training in order to increase self efficacy on career decision making of senior high school students. The subjects of this research was 104 students of Malang Islamic Senior High School. This research was using quasi experimental design one group pretest posttest. Self efficacy on career decision making scale was used to collect data. Results showed that posttest score higher than pretest, respectively, 114,02 and 109,80 ( $t=9,051 ; p=0,000)$, which means that SEFY Training can increase self efficacy on career decision making.
\end{abstract}

Key Words: Self Efficacy On Career Decision Making, Adolescent, SEFY Training

\begin{abstract}
ABSTRAK
Penelitian ini bertujuan untuk mengetahui apakah pelatihan SEFY berpengaruh dalam meningkatkan efikasi diri pengambilan keputusan karir pada siswa sekolah menengah atas. Subjek yang digunakan dalam penelitian ini sebanyak 104 siswa di SMA Islam Malang. Desain yang digunakan adalah kuasi eksperimen one group pretest posttest design. Metode pengumpulan data berupa skala efikasi diri keputusan karir yang sekaligus menjadi prates dan pascates. Hasil penelitian menunjukkan bahwa ada perbedaan jumlah rata-rata antara hasil prates sebesar 109,80 dan hasil pascates sebesar 114,02 ( $t=9,051 ; p=0,000)$ yang bermakna bahwa pelatihan SEFY mampu meningkatkan efikasi diri dalam pengambilan keputusan karir.
\end{abstract}

Kata kunci: Efikasi diri dalam pengambilan keputusan karir, Remaja, Pelatihan SEFY.

Siswa sekolah menengah atas atau kejuruan dalam tahap perkembangan karir adalah individu yang sedang mencapai tahap eksplorasi, yaitu tahap saat mereka sedang menggali pengetahuan tentang karir yang akan dipilih setelah lulus dari sekolah menengah atas atau kejuruan.
Mereka berada pada kategori remaja dengan umur 14-18 tahun. Pada tahap ini mereka memiliki tugas membangun dan mempersiapkan masa depan terutama karir. Menurut teori perkembangan karir yang dikemukakan oleh Super (Santrock, 2007), pada masa ini remaja mulai 
mengidentifikasi kesempatan dan tingkat pekerjaan yang sesuai, serta mengimplementasikan pilihan karir dengan memilih pendidikan dan pelatihan yang sesuai, yang nantinya mereka akan memilih memasuki pekerjaan atau melanjutkan pendidikan ke jenjang yang lebih tinggi agar mereka tidak menjadi pengangguran. Salah satu faktor yang memengaruhi keputusan mereka dalam memilih karir adalah efikasi diri (self efficacy).

Efikasi diri terkait erat dengan pengembangan karir. Merujuk pada Betz dan Hacket (Sersiana, 2012), efikasi diri akan karir seseorang adalah domain yang menggambarkan pendapat pribadi seseorang dalam hubungannya dengan proses pemilihan dan penyesuaian karir. Dengan demikian, efikasi diri akan karir seseorang dapat menjadi faktor penting dalam penentuan apakah intensi kewirausahaan seseorang sudah terbentuk pada tahapan awal seseorang memulai karirnya. Lebih lanjut, Betz dan Hacket menyatakan bahwa semakin tinggi tingkat efikasi diri seseorang pada kewirausahaan di masamasa awal seseorang dalam berkarir, semakin kuat intensi kewirausahaan yang dimilikinya. Selain itu, Gilles dan Rea (Sersiana, 2012) membuktikan pentingnya efikasi diri dalam proses pengambilan keputusan terkait dengan karir seseorang. Efikasi diri terbukti signifikan menjadi penentu intensi seseorang. Menurut Luthan (Sersiana, 2012), efikasi diri secara langsung mempengaruhi: (a) pemilihan perilaku (keputusan dibuat berdasarkan bagaimana efikasi yang dirasakan seseorang terhadap pilihan, misalnya tugas pekerjaan atau bidang karier). (b) Usaha motivasi (orang mencoba lebih keras berusaha melakukan tugas di mana efikasi diri mereka lebih tinggi daripada mereka yang memiliki penilaian efikasi rendah. (c) Daya tahan (orang dengan efikasi diri tinggi akan bangkit, bertahan saat menghadapi masalah atau kegagalan). Sementara orang dengan efikasi diri rendah cenderung menyerah saat muncul rintangan).(d) Daya tahan terhadap stres (orang dengan efikasi diri rendah cenderung mengalami stres dan kalah karena mereka gagal, sementara orang dengan efikasi diri tinggi, memasuki situasi penuh tekanan dengan percaya diri dan kepastian dengan demikian dapat menahan reaksi stres).

Efikasi diri, menurut Bandura (Alwisol, 2004), merupakan persepsi terhadap diri sendiri mengenai seberapa bagus diri dapat berfungsi dalam situasi tertentut. Efikasi diri berhubungan dengan keyakinan bahwa diri memiliki kemampuan melakukan tindakan yang diharapkan. Menurut Bandura (Rachmawati, 2012), efikasi diri merupakan hasil interaksi antara lingkungan eksternal, mekanisme penyesuaian diri serta kemampuan personal, pengalaman dan pendidikan. Efikasi diri adalah faktor penting dalam menentukan kontrol diri dan perubahan perilaku dalam individu.

Remaja dengan keyakinan diri yang tinggi akan mengatakan bahwa dirinya mampu memilih karir dan bertanggung jawab atas pilihan karirnya tersebut. 
Santrock (2007) dalam bukunya menjelaskan bahwa siswa dengan efikasi diri yang rendah akan menghindari tugastugas yang diberikan pada proses belajar, sedangkan siswa dengan efikasi diri yang tinggi akan bersemangat dalam mengerjakan setiap tugas yang diberikan pada proses belajar. Siswa dengan efikasi diri yang tinggi akan berusaha lebih keras dan bertahan lebih lama dalam proses belajar dibandingkan dengan siswa yang efikasi diri yang rendah. Selain itu, siswa dengan efikasi diri yang tinggi akan lebih memiliki rasa percaya diri dalam menjelajahi tantangan karir.

Penelitian yang dilakukan oleh Nota, Ferrari, Solberg dan Soresi (2007) pada 253 pemuda di Italia mengungkapkan bahwa dukungan keluarga terbukti berpengaruh baik untuk efikasi diri keputusan karir dan membuat keputusan karir. Tujuan dari penelitian menemukan bahwa, untuk remaja laki-laki pada jenjang sekolah tinggi perlu melakukan eksplorasi karir yang berkhasiat sebagai mediasi hubungan antara dukungan keluarga dan keraguan karir. Bertentangan dengan harapan, untuk remaja perempuan tidak ada hubungan langsung antara dukungan keluarga dan keraguan karir. Namun, dukungan keluarga langsung berhubungan dengan karir pencarian efikasi diri dan karier pencarian diri efikasi dikaitkan dengan kebimbangan karir. Oleh karena itu efikasi diri sangat dibutuhkan oleh siswa agar mereka dapat memilih dan mempersiapkan diri mema-suki dunia karir dengan baik.
Di Pakistan, Achta, Achter, Sujja, dan Shujjat (2013) melakukan study research yang bertujuan untuk menguji efikasi diri sebagai pengaruhNegative Career Though itu selesai dalam dua tahap. Tahap pertamater diri dari tryout, yang menunjukkan bahwa semua skala yang digunakan dalam penelitian ini mensyaratkan indeks memuaskan keandalan dan konsistensi internal. Tahap kedua terdiri dari utama studi pada sample purposive dari 256 orang lulusan. Usia sampel berkisar 24-37 tahun. Analisis korelasi menunjukkan bahwa efikasi diri berkorelasi negatif dengan NCT dan skala yang digunakannya. Analisis regresi linier menunjukkan efikasi diri sebagai prediktor negatif yang signifikan total NCT dan konstruksinya. Perbedaan gender yang signifikan yang ditunjukkan pada perbedaan efikasi diri yang dimiliki subjek.

Penelitian selanjutnya dilakukan di Turki oleh Bozgeyikli, Eroglu, dan Hamurcu (2009) yang mengangkat tema Status sosial ekonomi dari kaum muda adalah salah satu faktor penting yang berpenga-ruh terhadap keputusan baik karir mereka yang menyebabkan efikasi diri pada kematangan karir mereka. Penelitian ini dilakukan dengan metode survei dan itu mencoba untuk mengetahui pengaruh status sosial. Ekonomi pada variabel terkait dengan menggambarkan pengambilan keputusan karir efikasi diri dan kematangan karir anak muda yang berada pada status sosial ekonomi yang berbeda. Penelitian ini dilakukan dengan 346 orang muda di Turki yang ditentukan 
dengan metode random sampling. Hasil penelitian menunjukkan bahwa ada hubungan yang signifikan antara pengambilan keputusan karir efikasi diri dan kematangan karir dengan status sosial ekonomi. Di sisi lain diamati bahwa pengambilan keputusan karir efikasi diri dan kematangan karir orang-orang muda yang status sosial ekonomi yang berbedaberbeda dalam tingkat yang signifikan.

Dalam studi berskala besar oleh Csikzentmihalyi dan Schinder (Santrock, 2007) dipelajari bagaimana remaja AS mengembangkan sikap dan keterampilan yang diperlukan untuk mencapai tujuan dan harapan karirnya. Mereka mengukur 1000 siswa lebih yang berasal dari 13 sekolah daerah di penjuru Amerika Serikat. Pikiran-pikiran dan perasaan-perasaan para siswa mengenai apa yang dilakukan, dicatat secara acak. Mereka diminta mengisi kuisioner mengenai sekolah, keluarga, dan kawan-kawan sebaya, dan aspirasi karirnya. Peneliti juga mewawancarai para remaja dan rekan-rekannya, orang tua, dan guru. Hasil temuan yang diperoleh dari studi tersebut adalah para remaja perempuan mengantisipasi gaya hidup yang sama dengan remaja laki-laki dalam hal pendidikan dan penghasilan, para siswa minoritas yang berasal dari keluarga berpenghasilan rendah memiliki sikap yang lebih positif terhadap sekolah dibandingkan siswa kaya, para siswa yang memperoleh keuntungan besar dari sekolah dan memiliki harapan yang paling tinggi mengenai masa depannya merupakan siswa yang memandang sekolah sebagai tempat bermain dibandingkan tempat kerja, tujuan vokasional yang jelas dan pengalaman kerja yang baik tidak menjamin transisi yang baik untuk memasuki dunia kerja orang dewasa. Aktivitasaktivitas yang dilakukan, keterlibatan yang intensif terlepas dari isi dan aktivitas tersebut, penting untuk mengembangkan optimisme dan daya tahan untuk mencapai kehidupan kerja yang memuas-kan.

Selanjutnya di Indonesia, menurut Moesono (Hambal \& Agustini, 2012), diketahui bahwa ternyata siswa SMA tidak pernah betul-betul tahu apa yang diinginkannya, tidak terbiasa tertantang menggali informasi sampai tuntas, namun hanya bermodal informasi yang hanya $40 \%$, petunjuk orang tua, dan keberanian beresiko. Penelitian yang dilakukan oleh Jamilah (Hambal \& Agustini, 2012) mengenai hambatan-hambatan yang memengaruhi ketepatan pilihan karir siswa. Hasil dari penelitian tersebut terdapat hambatan internal dan hambatan eksternal. Salah satu hambatan eksternal adalah orang tua dan presentasenya $79,1 \%$, yaitu pada kategori tinggi, artinya bahwa dalam pemilihan karir siswa orang tua kurang mendukung serta terlalu memaksakan keinginan atau kehendaknya terhadap karir yang dipilih anaknya bahkan siswa tidak memiliki pilihan pekerjaan atau karir.

Penelitian Hayadin (Hambal \& Agustini, 2012) di sejumlah Sekolah Menengah Atas (SMA), Madrasah Aliyah (MA), dan Sekolah Menengah Kejuruan (SMK) di Jakarta, memberikan gambaran 
bahwa 35,75\% siswa kelas XII sudah mempunyai pilihan pekerjaan dan profesi, sementara $64,25 \%$ belum memiliki pilihan pekerjaan dan profesi. Pada dasarnya siswa yang belum memiliki pilihan pekerjaan dan profesi tersebut merupakan siswa yang memiliki prestasi akademik sedang hingga tinggi. Berdasarkan sejumlah fakta tersebut, dapat disimpulkan bahwa sebagian besar siswa kelas XII belum mampu merencanakan karirnya dengan baik.

Dalam kenyataannya, banyak siswa yang mengalami keraguan dalam memilih karir yang akan menunjang masa depan mereka. Ada yang ingin bekerja namun orang tua memaksa untuk melanjutkan ke perguruan tinggi. Ada juga yang ingin ke perguruan tinggi namun keadaan keuangan keluarga yang memaksakan mereka untuk bekerja. Ada juga permasalahan dari mereka yaitu dipercaya keluarga untuk meneruskan usaha keluarga namun mereka ragu akan kemampuan mereka yang hanya lulus sekolah menengah atas. Jika dilihat dari permasalahan di atas mereka tidak memiliki efikasi diri akan keputusan yang akan mereka pilih permasalahan yang muncul dan menyebabkan efikasi diri akan pengambilan keputusan karir mereka rendah.

SMA Y Malang merupakan salah satu sekolah swasta di kota Malang. SMA ini memiliki kelengkapan segala akses baik berupa komputer, internet, perpustakaan dengan buku yang lengkap, ruangan dengan fasilitas yang sangat memadai, memiliki tujuh kelas untuk kelas $\mathrm{X}$, delapan kelas untuk kelas $\mathrm{XI}$, dan tujuh kelas untuk kelas XII. Namun, dari pengakuan yang diberikan guru BK secara langsung kepada peneliti diketahui bahwa walaupun fasilitas di sekolah mereka sangat mencukupi tetapi jam mata pelajaran bimbingan dan konseling telah dikurangi yang tadinya 65 menit menjadi 45 menit. Hal tersebut terjadi karena mata pelajaran inti seperti matematika, fisika, kimia, biologi dan ekonomi semakin diperpanjang dan diperketat oleh pihak pemerintahan. Hal tersebut menyebabkan sekolah mengurangi waktu bermain dan belajar tentang bimbingan dan konseling. Selain hal tersebut, pihak sekolah pun tidak pernah memberikan fasilitas berupa pemahaman akan bakat dan minat siswa, keyakinan akan bakat dan minat yang mereka miliki, atau pelatihan-pelatihan yang dapat menimbulkan berbagai bakat minat siswa yang terpendam dan akan mempengaruhi mereka untuk menentukan keputusan karir yang akan mereka pilih setelah lulus SMA.

Selain pelatihan, guru BK di SMA tersebut mengatakan bahwa dukungan keluarga dan status sosial ekonomi sangat berpengaruh dalam penentuan karir setelah lulus sekolah. Mereka mengalami kebingungan karir karena apa yang mereka inginkan tidak sesuai dengan apa yang orang tua mereka inginkan. Terdapat siswa yang melakukan konsultasi berulang kali dengan guru BK bahwa mereka ingin berkuliah di suatu jurusan namun orang tua mereka menghendaki jurusan yang lain. Kebanyakan orang tua murid me- 
maksakan jurusan yang orang tua kehendaki karena yang membiayai kelanjutan dalam karir mereka adalah orang tua. Adapula mereka yang ingin melanjutkan ke perguruan tinggi, namun keadaan ekonomi mereka yang tidak memungkinkan dan mengharuskan mereka untuk bekerja, sedangkan adapula siswa dengan status ekonomi yang tinggi dan berkecukupan memilih untuk bersantai dirumah dan menikmati kekayaan yang orang tua mereka miliki.

Hal tersebut yang menjadi dasar peneliti perlu mengadakan pelatihan untuk membantu siswa agar efikasi diri akan keputusan karir tumbuh dan memperkuat keyakinan diri mereka akan keputusan karir yang mereka pilih untuk menentukan masa depan mereka.

Berdasarkan uraian kajian di atas, maka hipote-sis penelitian yang diajukan adalah pelatihan SEFY mampu memengaruhi meningkatnya efikasi diri dalam pengambilan keputusan karir pada subjek.

\section{METODE PENELITIAN}

\section{Desain Penelitian}

Penelitian ini merupakan penelitian eksperimen dengan desain one-group pretest-posttest design. Variabel terikat dalam penelitian ini adalah efikasi diri dalam pengambilan keputusan karir, sedangkan variabel bebas dalam penelitian ini adalah efektivitas pelatihan SEFY. Pada awal penelitian ini dilakukan pengukuran terhadap variabel terikat yang telah dimiliki subjek. Pada pengukuran ini menggunakan skala efikasi diri dalam pengambilan keputusan karir. Setelah itu diberikan manipulasi, berupa pemberian materi di dalam ruangan atau aula yang berisikan tentang bagaimana cara agar siswa yakin akan keputusan karir yang mereka pilih, beserta out bond yang membantu meningkatkan efikasi diri pada siswa. Setelah dilakukan manipulasi, dilakukan pengukuran kembali dengan skala yang sama terhadap variabel terikat. Efektivitas atau pengaruh variabel bebas terhadap variabel terikat dilihat dari perbedaan antara prates dengan pascates.

\section{Subjek Penelitian}

Karakteristik subjek dalam penelitian ini adalah siswa dengan kategori remaja yang memiliki umur $14-18$ tahun yang bersekolah di SMA Y Malang. Berikut adalah perbandingan jumlah subjek yang mengikuti pelatihan SEFY berdasarkan jenis kelamin dapat dilihat pada tabel 1 di bawah ini :

Tabel 1. Deskripsi subjek penelitian berdasarkan jenis kelamin

\begin{tabular}{lll}
\hline Jenis Kelamin & $\begin{array}{l}\text { Jumlah } \\
\text { Responden }\end{array}$ & Prosentase \\
\hline Laki-laki & 56 & $\mathbf{4 3 , 7 5 \%}$ \\
Perempuan & 72 & $56,25 \%$ \\
\hline Jumlah & $\mathbf{1 2 8}$ & $\mathbf{1 0 0} \%$ \\
\hline
\end{tabular}

Berdasarkan tabel 1, subjek penelitian yang mengikuti pelatihan SEFY adalah 128 orang dengan jenis kelamin yang berbeda. Subjek terdiri dari 56 siswa atau $43,75 \%$ berjenis kelamin laki-laki 
dan 72 siswa atau $56,25 \%$ berjenis kelamin perempuan.

\section{Metode Pengumpulan Data}

Pada proses selanjutnya dalam penelitian ini adalah menentukan instrumen penelitian, yaitu untuk mendapatkan data yang relevan dengan tujuan penelitian dan juga memiliki reliabilitas dan validitas sebaik mungkin. Data awal untuk mengungkap seberapa jauh perkembangan karir siswa adalah menggunakan dokumentasi yang diperoleh melalui guru BK SMA Y Malang.

Kemudian metode pengumpulan data selanjutnya yang digunakan adalah instrumen dalam bentuk skala. Skala merupakan simbol atau angka yang disusun dengan cara tertentu sehingga simbol atau angka tersebut dengan aturan tertentu dapat diberikan kepada individu (perilaku individu) yang terhadapnya skala itu dikenakan, sedangkan pemberi- an simbol atau angka tadi mengikuti petunjuk tentang pemilikan individu terhadap apapun yang hendak diukur oleh skala tertentu, menurut Kerlinger (Seniati, 2011). Sedangkan instrumen yang digunakan untuk pengumpulan data dalam penelitian ini adalah skala pengukuran psikologis efikasi diri keputusan karir. Skala yang digunakan dalam penelitian ini adalah menggunakan skala Likert. Dalam penyusunannya skala Likert ini berisikan poin yang menunjukkan sangat yakin $(\mathrm{SY})$, yakin $(\mathrm{Y})$, ragu-ragu $(\mathrm{R})$, tidak yakin (TY), sangat tidak yakin (STY). Item pernyataan terdiri dari item-item yang bersifat favourable yang mendukung terhadap indikator variabel yang diungkap dan item unfavourable yang indikator variabelnya tidak mendukung terhadap variabel yang diungkap. Dalam penelitian ini, skala yang digunakan adalah skala efikasi diri dalam pengambilan keputusan karir.

Tabel 2. Indeks Validitas Skala Efikasi diri dalam pengambilan keputusan karir

\begin{tabular}{lcccc}
\hline Dimensi & Total item & Jumlah & $\begin{array}{c}\text { Jumlah } \\
\text { item gugur }\end{array}$ & $\begin{array}{c}\text { Indeks validitas } \\
\text { item terpakai }\end{array}$ \\
\hline Levellmagnitude & 13 & 3 & 10 & $0,266-0,601$ \\
Strength & 12 & 6 & 6 & $0,257-0,455$ \\
Generality & 13 & 3 & 10 & $0,328-0,578$ \\
\hline Total & $\mathbf{3 6}$ & $\mathbf{1 2}$ & $\mathbf{2 6}$ & \\
\hline
\end{tabular}

Dari tabel 2 dapat dilihat bahwa efikasi diri keputusan karir memiliki tiga aspek, yaitu levellmagnitude sebanyak 10 item dengan indeks validitas berkisar $0,266-0,601$, strength sebanyak 6 item dengan indeks validitas sebesar 0,257 -
0,455, dan generality sebanyak 10 item yang valid dari 38 item denagan indekss validitas berkisar $0,328-0,578$ dan telah gugur 12 item setelah dilakukan try out skala. 
Tabel 3. Indeks Reliabilitas Skala Efikasi diri dalam pengambilan keputusan karir

\begin{tabular}{lcc}
\hline Variabel & $\begin{array}{c}\text { Cronbach's } \\
\text { Alpha }\end{array}$ & Keterangan \\
\hline Efikasi diri & 0,862 & Reliabel \\
keputusan karir & & \\
\hline
\end{tabular}

Dari tabel 3 dapat dilihat bahwa skala efikasi diri dalam pengambilan keputusan karir mendapatkan nilai cronbach's alpha sebesar 0,862 yang menyatakan bahwa skala tersebut reliabel.

\section{Intervensi}

Merupakan pelatihan yang dirancang untuk meningkatkan efikasi diri. Pelatihan ini mencakup pelatihan yang meningkatkan kemampuan kognisi, afeksi, dan psikomotorik. Dalam penelitian ini subjek yang mengikuti pelatihan adalah siswa yang memiliki kategori remaja, berkisar antara umur 14-18 tahun. Dalam pelatihan Sefy ini, metode yang digunakan dalam pengumpulan data adalah data sekunder yang dimiliki oleh guru BK untuk menggali informasi tentang seberapa besar efikasi diri terhadap pengambilan keputusan karir yang dimiliki oleh siswa SMA Y Malang. Setelah didapatkan informasi data sekunder dan dokumentasi, dilanjutkan dengan penggalian lebih dalam kepada siswa SMA tersebut yaitu penyebaran angket efikasi diri pengambilan keputusan karir merupakan metode pengumpulan data berupa pretest design. Setelah pemberian angket, metode yang digunakan yaitu kuasi eksperimen atau eksperimen semu merupakan desain eksperimen yang pengendaliannya terhadap variabel-variabel non-eksperimental tidak begitu ketat, penentuan sampelnya dilakukan dengan tidak randomisasi (Latipun, 2004). Desain kuasi eksperimen tersebut berupa pemberian materi dan pemahaman tentang perlunya keyakinan diri terhadap keputusan karir kepada siswa. Materi ini diberikan di dalam ruangan, games mematahkan pensil dengan jari telunjuk. Seluruh peserta diberikan kesempatan untuk mencoba games mematahkan pensil dengan jari telunjuk games ini terbukti untuk menumbuhkan keyakinan diri dalam diri mereka.

Setelah seluruh siswa melakukan games tersebut, feedback pun diberikan agar keyakinan mereka semakin tumbuh dalam pengambilan keputusan dan dikaitkan dalam pemilihan karir. Setelah dilakukan feedback, pelatihan sefy pun dilanjutkan kembali. Selanjutnya pelatihan ini dilanjutkan dengan pemberian ice breaking. Dengan berakhirnya ice breaking maka siswa diberikan angket kembali sebagai pascates design dengan angket yang sama, yaitu angket self efiicacy dalam pengambilan keputusan karir.

\section{Metode Analisis Data}

Untuk mengetahui efektivitas atau pengaruh pelatihan sefy untuk meningkatkan efikasi diri dalam pengambilan keputusan karir pada siswa sekolah menengah atas di SMA Islam Malang. Proses pengolahan data, dan perhitungan-perhitungan statistik, dilakukan dengan menggunakan program SPSS versi 13.00. Analisis data 
yang digunakan pada penelitian ini adalah paired sample t-test, karena paired sample t- test merupakan prosedur yang digunakan untuk membandingkan ratarata dua variabel dalam satu group. Yang berarti bahwa apakah ada pengaruh pelatihan sefy terhadap efikasi diri dalam pengambilan keputusan karir siswa sekolah menengah atas kelas XII.

\section{HASIL PENELITIAN}

\section{Hasil Analisis Deskriptif}

Tabel di bawah ini menunjukkan penyebaran tingkat efikasi diri keputusan karir. Dari keseluruhan subjek hanya yang tergolong pada kategori rendah, sedang, dan tinggi saja yang datanya akan dianalisis untuk menguji hipotesis apakah terjadi peningkatan efikasi diridalam pengambilan keputusan karir pada siswa SMA Malang.

\section{Tabel 4. Rangkuman deskripsi subjek}

\begin{tabular}{cccc}
\hline Skor & Kategori & Jumlah & Prosentase \\
\hline$<91,87$ & Sangat Rendah & 11 & $8,6 \%$ \\
$91,87-103,13$ & Rendah & 25 & $19,5 \%$ \\
$103,14-114,39$ & Sedang & 49 & $38,3 \%$ \\
$114,40-125,65$ & Tinggi & 30 & $29,7 \%$ \\
$>125,66$ & Sangat Tinggi & 13 & $3,9 \%$ \\
\hline & & $\mathbf{1 2 8}$ & $\mathbf{1 0 0} \%$ \\
\hline
\end{tabular}

Dalam penelitian ini subjek yang mengikuti pelatihan SEFY sebanyak 128 siswa. Namun yang dianalisis adalah yang berada pada kategori rendah, sedang dan tinggi yang diperoleh dari analisis menggunakan tekhnik analisis zscore dan memperoleh 104 subjek. Lalu analisis selanjutnya menggunakan tekhnik analisis paired sample t-test dan telah mendapatkan hasil yang akan dijelaskan pada tabel 5 berikut ini:

Tabel 5. Rangkuman deskripsi data paired samples statistics

\begin{tabular}{lcc}
\hline Desain & Jumlah Subjek & Mean \\
\hline Prates & 104 & 109,80 \\
Pascates & 104 & 114,02 \\
\hline
\end{tabular}

Pada tabel di atas, menunjukkan hasil rata-rata dari prates sebesar 109,80 sedangkan hasil pascates sebesar 114,02. Hasil perbedaan terlihat karena terdapat perubahan efikasi diri keputusan karir sebelum dan sesudah mengikuti pelatihan SEFY. Hal tersebut menunjukkan bahwa pelatihan SEFY mampu mempengaruhi meningkatnya efikasi diridalam pengambilan keputusan karir pada subjek penelitian.

Tabel 6. Hasil paired samples test

\begin{tabular}{lccc}
\hline $\begin{array}{l}\text { Pascastes - Prates } \\
\text { Kesimpulan }\end{array}$ & t & p & Keterangan \\
\hline $\begin{array}{l}4,221 \\
\text { Signifikan }\end{array}$ & 9,051 & 0,000 & $\mathrm{p}<0,05$ \\
\hline
\end{tabular}


Pada tabel di atas menunjukkan hasil bahwa selisih nilai rata-rata dari nilai pascates dan prates adalah sebesar 4,221dengan nilai $\mathrm{t}=9,051$ dan nilai $\mathrm{p}$ $=0,000$. Hal ini menunjukkan bahwa ada perbedaan secara signifikan pada efikasi diri keputusan karir sebelum mengikuti dan setelah mengikuti pelatihan SEFY. Secara keseluruhan pelatihan SEFY dapat mempengaruhi meningkatnya efikasi diridalam pengambilan keputusan karir pada subjek.

\section{PEMBAHASAN}

Berdasarkan penjelasan di atas, dapat dilihat bahwa subjek yang mengalami peningkatan efikasi diri dalam pengambilan keputusan karir sebanyak 84 siswa, dan penurunan efikasi diri dalam pengambilan keputusan karir juga terjadi pada 44 siswa. Hal tersebut dapat dilihat dari jumlah prates dan pascates. Setelah mendapatkan hasil dari skala menggunakan zscore diperoleh tiga kelompok yang akan dianalisis menggunakan paired sample t-test, yaitu kelompok rendah, sedang dan tinggi menjadi 104 siswa. Perolehan hasil rata-rata setelah dianalisis pada nilai prates 109,80 setelah memperoleh pelatihan SEFY. Perubahan nilai ratarata terjadi atau pascates sebesar 114,02. Hal tersebut menunjukkan nilai perbandingan sebesar 4,221. Selain dilihat dari hasil rata-rata, efektivitas pelatihan juga dapat dilihat dari perolehan yang signifikan dengan nilai (p) sebesar 0,000 $<$ 0,05 serta nilai $t$ hitung yang didapatkan adalah sebesar 9,051. Hasil tersebut menunjukkan bahwa pelatihan SEFY mampu meningkatkan efikasi diri keputusan karir pada subjek. Hal tersebut dapat diartikan bahwa secara keseluruhan pelatihan SEFY mampu meningkatkan efikasi diri keputusan karir pada subjek.

Selain itu penelitian kuasi eksperimen tentang pelatihan kreativitas untuk meningkatkan efikasi diri. Peneliti mengembangkan pelatihan kreativitas didasarkan pada teori kognitif sosial. Penelitian ini dilakukan dalam dua format: pelatihan lima hari dan pelatihan satu hari penuh. Sampel terdiri atas mahasiswa dan karyawan kota dilakukan selama lima hari, dan guru pendidikan khusus dilakukan selama sehari saja. Siswa dari mathematics dan statistika merupakan kontrol kelompok. Peneliti mengukur efikasi diri sebelum dan setelah intervensi, dan efikasi diri meningkat secara signifikan untuk ke lima hari dan kursus satu hari, sedangkan kelompok kontrol tidak menunjukkan perubahan efikasi diri. Tingkat efikasi diri meningkat signifikan bagi siswa dan karyawa kota. Sebuah tindak lanjut penilaian yang dilakukan selama dua bulan setelah menyelesaikan pelatihan selama lima hari tidak menunjukkan penurunan efikasi diri yang mereka miliki. Sebagaimana diungkapkan Bandura (Alwisol 2004), efikasi diri dapat diubah sehingga bisa diting-katkan melalui salah satu kombinasi empat sumber, yakni pengalaman menguasai sesuatu prestasi dimasa lalu (performance accomplishment), pengalaman vikarius mengamati orang yang 
membuat keyakinan diri muncul (vicarius experience), persuasi sosial (social persuation), dan pembangkitan emosi (emotional/ phyisiological state).

Setelah metode yang telah dikemukakan sebelumnya, ada pula faktor penyebab perbedaaan yang mempengaruhi mengapa ada siswa yang efikasi diri meningkat setelah mengikuti pelatihan SEFY, dan faktor yang menyebabkan mengapa siswa memiliki efikasi diri yang rendah. Constantine, Wallace. Kindaichi (2005), meneliti sejauh mana hambatan karir yang dialami dan dukungan orang tua yang dirasakan diprediksi menjadi pengaruh yang kuat untuk mengambil keputusan karir dan kebingungan karir. Sampel pada penelitian ini adalah siswa SMA Afrika dan Amerika yang berada di Columbia. Mereka mendapatkan hasil, bahwa siswa mengalami kebingungan dalam pengambilan keputusan karir karena terjadi kesenjangan sosial antara siswa Afrika dan siswa Amerika. Persepsi masyarakat di Amerika yang menganggap bahwa siswa Amerika yang memiliki kedudukan lebih tinggi dan hal tersebut yang menyebabkan siswa Afrika memiliki efikasi diri yang rendah dari pada siswa Amerika. Selain hal tersebut, dukungan orang tua dan saudara yang sangat berpengaruh dan berperan penting dalam efikasi diri pengambilan keputusan karir setelah lulus dari sekolah menengah atas. Selain di Amerika Afrika, penelitian di Turki yang dilakukan oleh Onder \& Isik (2010) menghasilkan bahwa orang tua dan pola asuh di dalam keluarganya sangat signifikan mempengaruhi pengambilan keputusan karir. Keadaan keuangan keluarga juga memengaruhi pemilihan karir mereka. Di Turki siswa yang terlahir dengan keluarga kaya raya akan merasakan duduk di bangku perkuliahan sedangkan siswa yang terlahir dari keluarga yang berkecu-kupan akan bekerja untuk menghasilkan uang.

\section{SIMPULAN DAN SARAN}

\section{Simpulan}

Hasil dari penelitian eksperimen ini menunjukkan bahwa pelatihan SEFY memiliki pengaruh yang signifikan terhadap meningkatnya efikasi diri keputusan karir pada siswa Sekolah Menengah Atas Y Malang. Hal tersebut dapat dibuktikan dengan nilai probabilitas uji statistik yang mendapatkan perolehan nilai $p=0,000$ yang bermakna signifikan karena $\mathrm{p}<0,05$ dan nilai t hitung yang diperoleh adalah sebesar 9,051. Pelatihan ini menggunakan subjek sebanyak 128 siswa. Setelah itu dianalisis dengan menggunakan zscore untuk mengelompokkan ke dalam kategori rendah, sedang, tinggi. Hasilnya 25 siswa masuk ke dalam kategori rendah, 45 siswa yang masuk ke dalam kategori sedang, dan 38 siswa yang masuk ke dalam kategori tinggi. Jumlah vital keseluruhan siswa yang di analisis adalah sebanyak 104 siswa.

Analisis selanjutnya menggunakan paired sample t-test membandingkan antara prates dan pascates. Hasil nilai rata-rata prates sebesar 109,80 dan nilai 
rata-rata pascates. Hasil perbedaan ratarata antara nilai prates dan pascates terlihat karena terdapat perubahan efikasi diri keputusan karir sebelum dan sesudah mengikuti pelatihan SEFY sebesar 4,221. Selain pelatihan yang mempengaruhi keputusan karir yang akan mereka ambil, faktor sosial ekonomi dan keinginan keluarga sangat berpengaruh. Hal tersebut dapat dibuktikan secara langsung dari hasil wawancara dengan guru BK di SMA tersebut. Perbedaan antara keinginan orang tua dan keinginan subjek antar memilih melanjutkan karir di perguruan tinggi dan memilih bekerja karena faktor ekonomi, serta keyakinan dalam dirinya dalam mengambil suatu keputusan dalam berkarir setelah lulus sekolah adalah penyebab keraguan dalam pengambilan keputusan karir.

\section{Implikasi}

Dalam penelitian ini, peneliti menyarankan kepada berbagai pihak. Pertama, bagi pihak sekolah SMA Malang diharapkan agar pihak sekolah memberikan fasilitas untuk meningkatkan efikasi diri keputusan karir pada siswa seperti training atau gambaran bagaimana dunia kerja dan dunia perkuliahan. Hal tersebut dapat mengurangi kebingungan siswa terhadap keputusan karir yang akan mereka pilih setelah lulus sekolah.Kedua, bagi lingkungan sekitar diharapkan lingkungan sekitar atau orang tua, saudara dan teman-teman untuk mendukung anaknya jika telah memutuskan pilihan karir. Karena dengan dukungan keluarga dan lingkunganlah anak-anak mampu menjadi pribadi yang semangat dan lebih bertanggung jawab atas pilihan yang mereka pilih. Ketiga, bagi Siswa SMA Islam Malang diharapkan mampu menggunakan fasilitas media internet untuk mencari informasi tentang dunia pekerjaan atau dunia perkuliahan yang akan mereka hadapi setelah lulus sekolah. Belajar semaksimal mungkin, karena masa depan yang cerah akan didapatkan sesuai dengan kerja keras yang kalian lakukan.

Kelemahan penelitian: Pertama, penelitian ini tidak ada pelaksanaan uji coba modul yang dilakukan oleh peneliti. Kedua, penelitian ini, mampu mempengaruhi efikasi diri siswa lebih baik lagi jika waktu yang diberikan pihak sekolah lebih banyak. Ketiga, metode dalam penelitian eksperimen ini terdiri dari materi pengetahuan dan hanya satu permainan yang dikategorikan mampu meningkatkan efikasi diri. Untuk peneliti selanjutnya diharapkan mampu memberikan jenis permainan yang lain yang mampu meningkatkan efikasi diri. Keempat, variabel subjek dalam penelitian ini ditinjau secara keseluruhan tidak membedakan jenis kelamin atau kelas.

Adapun saran bagi peneliti selanjutnya: Pertama, sebelum melakukan penelitian ini, diharapkan peneliti selanjutnya melakukan uji coba modul terlebih dahulu agar dapat membuktikan bahwa pelatihan ini layak untuk di eksperimenkan. Kedua, diharapkan mampu mengembangkan metode eksperimen yang telah 
dibuat oleh peneliti. Ketiga, metode eksperimen yang telah tersedia dapat digunakan untuk berbagai macam jenis subjek seperti siswa sekolah dasar, siswa sekolah menengah, dan mahasiswa. Keempat, diharapkan peneliti selanjutnya membedakan variabel subjek yang akan digunakan dalam penelitian eksperimen selanjutnya.

\section{DAFTAR PUSTAKA}

Achta, M, Achter, N, Sujja, S \& Shujjat, J.M (2013). Impact of Self-Efficacy on Negative Career Thoughts in University Graduates: University Of Sargodah Pakistan. International Journal of Business and Social Science, 4, 263 - 269.

Alwisol. (2009). Psikologi Kepribadian. Malang: UMM Press.

Bozgeyikli, H, Eroglu, S.E, \& Hamurcu, H. (2009). Career Decision Making Self-Efficacy, Career Maturity And Socioeconomic Status With Turkish Youth: Georgian Electronic Scientific Journal. Education Science and Psychology, 14, 15 - 24.

Constantine, M.G, Wallace, B.C. \& Kindaichi, M.M. (2005). Examining Contextual Factors In The Career Decision Status Of African American Adolescents: Teachers College, Columbia University.
Journal Of Career Assessment, 13 (3), $307-319$.

Hanifah, N.H \& Agustini, R. (2012). Peningkatan Self Efficacy Dan Berpikir Kritis Melalui Penerapan Model Pembelajaran Inkuiri Materi Pokok Asam Basa Kelas XI SMAN Surabaya: Unesa Journal of Chemical Education, 1, 27 - 33.

Latipun. (2004). Psikologi Eksperimen Edisi Kedua. Malang: UMM Press.

Nota, L, Ferrari, L, Solberg, V.S.H. \& Soresi, S. (2007). Career Search Self Efficacy, Family Support, and Career Indecision With Italian Youth: Sage Publication. Journal of Career Assessment, 15, 181-193.

Onder, F.C, Kirdok, O, \& Isik, E. (2010). High School Students Career Decision-Making Pattern Across Parenting Styles And Parental Attachment Levels: Psychological Counseling \& Guidance Cukurova University, Adana, Turkey. Electronikal sJournal Of Research In Educational Psychology, 8 (1), 263 $-280$.

Santrock, J. W. (2007). Remaja (11 $1^{\text {th }}$ ed). (Terj. B.Widyasinta). Jakarta: Erlangga. 
Seniati, L, Yulianto, A. Setiadi, B.N. Sersiana.(2012). Efektivitas Pelatihan (2011). Psikologi Eksperimen. Jakarta: PT. Indeks. Kreativitas untuk meningkatkan self efficacy pada mahasiswa dan karyawan kotamadya di Surabaya: JurnalUniversitas Airlangga,3, 1-24. 